\title{
ORIGINAL ARTICLE \\ Antioxidant and hepatoprotective effect of Garcinia indica fruit rind in ethanol- induced hepatic damage in rodents
}

\author{
Vandana PANDA ${ }^{1}$, Hardik ASHAR ${ }^{1}$, Sudhamani SRINATH ${ }^{2}$ \\ 1 Department of Pharmacology \& Toxicology, Prin. K. M. Kundnani College of Pharmacy, Rambhau Salgaonkar Marg, Cuffe Parade, Colaba, Mumbai, India \\ 2 Department of Pathology, Dr. D.Y. Patil Medical College, Nerul, Navi Mumbai, India
}

ITX050412A07 • Received:27 April 2012 • Revised: 12 September 2012 • Accepted: 19 September 2012

\begin{abstract}
The protective effects of aqueous extracts of the fruit rind of Garcinia indica (GIE) on ethanol-induced hepatotoxicity and the probable mechanisms involved in this protection were investigated in rats. Liver damage was induced in rats by administering ethanol (5 g/kg, 20\% w/v p.o.) once daily for 21 days. GIE at 400 mg/kg and 800 mg/kg and the reference drug silymarin (200 mg/kg) were administered orally for 28 days to ethanol treated rats, this treatment beginning 7 days prior to the commencement of ethanol administration. Levels of marker enzymes (aspartate aminotransferase (AST), alanine aminotransferase (ALT) and alkaline phosphatase (ALP)), triglyceride (STG), albumin (Alb) and total protein (TP) were evaluated in serum. Antioxidant parameters (reduced glutathione (GSH), superoxide dismutase (SOD), catalase (CAT), glutathione peroxidase (GPx) and glutathione reductase (GR)), hepatic triglycerides (hTG) and the lipid peroxidation marker malondialdehyde (MDA) were determined in liver. GIE and silymarin elicited significant hepatoprotective activity by attenuating the ethanol-elevated levels of AST, ALT, ALP, STG, hTG and MDA and restored the ethanol-depleted levels of GSH, SOD, CAT, GPx, GR, Alb and TP. GIE 800 mg/kg demonstrated greater hepatoprotection than GIE $400 \mathrm{mg} / \mathrm{kg}$. The present findings indicate that hepatoprotective effects of GIE in ethanol-induced oxidative damage may be due to an augmentation of the endogenous antioxidants and inhibition of lipid peroxidation in liver.
\end{abstract}

KEY WORDS: Garcinia indica; ethanol; hepatoprotective; antioxidant activity

\section{Introduction}

"Leave your drugs in the chemist's pot if you can heal the patient with food", the famous words of Hippocrates, the father of medicine have come of age. Recently, with the advent of functional foods and nutraceuticals, the focus has shifted to evaluation of dietary components, including fruits and vegetables as possible therapeutic interventions.

Garcinia indica Choisy (Family: Clusiaceae/ Guttiferae), a slender evergreen tree is endemic to the west coast of India (Khare, 2007). It has many culinary, pharmaceutical and industrial uses. The dried rind known as "kokum" is an Indian spice and condiment used in many parts of the country for making several "curry" preparations. Syrup made from the fruits is a healthy soft

\footnotetext{
Correspondence addres:

Dr. Vandana Panda

Prin. K. M. Kundnani College of Pharmacy,

Jote Joy Building, Rambhau Salgaonkar Marg

Cuffe Parade, Colaba, Mumbai 400005, India.

TEL.: +9122 22164387 • FAX +9122 22165282

E-MAIL: vspanda@rediffmail.com
}

drink used during summer to relieve sun stroke. Many therapeutic effects of the fruit have been described in Ayurveda, which include its usefulness as an infusion and in skin ailments such as rashes caused by allergies; in treatment of burns, scalds and chaffed skin; as a remedy for dysentery and mucous diarrhea; as an appetizer and a good liver tonic; as a cardiotonic and for bleeding, piles, tumors and heart diseases (Shastri, 1956).

One of the ingredients of kokum, hydroxycitric acid (HCA), has been patented for use as a hypocholesterolemic agent (Jena et al., 2002). Another constituent from G. indica, Garcinol, a polyisoprenylated benzophenone has been reported to be an antioxidant (Devasagayam et al., 2006; Krishnamurthy \& Sampathu, 1988), a glycation inhibitor (Yamaguchi et al., 2000a), and an antiulcer agent (Yamaguchi et al., 2000b). It possesses a strong growthinhibitory effect against human leukemia HL-60 cells (Pan et al., 2001). Garcinol also shows antibacterial activity against Methicillin-resistant Staphylococcus aureus, comparable with that of the antibiotic Vancomycin (Rukachaisirikul et al., 2005; Iinuma et al., 1996). It is a natural histone acetylase transferase inhibitor both in 
vitro and in vivo, suggesting its implication in a wide variety of diseases like cancer and AIDS (Balasubramanyam et al., 2004; Mantelingu et al., 2007). Apart from HCA and garcinol, kokum contains other compounds like citric acid, malic acid, polyphenols, anthocyanin pigments and ascorbic acid with potent antioxidant properties (Padhye et al., 2009). It is well known that heavy consumption of alcohol is associated with liver damage. Experimental animals exposed to two-carbon alcohol display biochemical signs of hepatotoxicity and oxidative damage, suggesting a possible role of free radicals in causing some of the toxic effects of alcohol (Albano et al., 1999). The close relation between ethanol (ETOH) and liver damage is mainly due to the fact that about $80 \%$ of ingested alcohol is metabolized in the liver. Ethanol is metabolized to the cytotoxic acetaldehyde by the enzyme alcohol dehydrogenase in the liver. Acetaldehyde is oxidized to acetate by aldehyde oxidase or xanthine oxidase, giving rise to reactive oxygen species (ROS) via cytochrome P450 2E1 (CYP 2E1) (Tuma \& Casey, 2003). Excessive alcohol consumption not only enhances ROS generation, but also depletes antioxidants, thus creating a state of oxidative stress leading to severe liver injury (Wu \& Cederbaum, 2003).

Traditionally, the syrup of G. indica has been administered to alcohol intoxicated individuals for liver protection. Aqueous extracts of G. indica have been reported to possess potent antioxidant, free radical scavenging and anti-lipid peroxidative activities (Devasagayam et al., 2006). Promising results of our previous study, the hepatoprotective effects of $\mathrm{G}$. indica in $\mathrm{CCl}_{4}$-induced hepatotoxicity in rats, encouraged us to further explore this area (Panda \& Ashar, 2012). With this background, the present study was carried out to investigate the hepatoprotective effect and a possible underlying antioxidant activity of aqueous extracts of the fruit rind of G. indica by assaying various marker enzymes, antioxidant enzymes and GSH in chronically ethanol fed rats.

\section{Material and methods}

\section{Plant material}

The fruit rind of G. indica was collected from the Konkan region of Maharashtra and air dried under shade, powdered mechanically and stored in an air tight container. The powder was extracted using soxhlet apparatus and water as solvent and stored in a refrigerator for further use. The plant was authenticated at the Blatter Herbarium, St. Xavier's College, Mumbai, after matching with the existing specimen (accession no. 03587).

\section{Drugs and chemicals}

Silymarin was a gift from Ranbaxy Laboratories, Delhi, India. Thiobarbituric acid (TBA), reduced glutathione, oxidized glutathione and nicotinamide adenine dinucleotide phosphate (NADPH) were obtained from Himedia Laboratories, Mumbai, India. Epinephrine and 5, 5'-dithiobis (2-nitrobenzoic acid) - (DTNB) were purchased from Sigma Chemical Co., St Louis, MO, USA.
All other chemicals were obtained from local sources and were of analytical grade.

\section{Experimental animals}

Wistar albino rats (150-200 g) of either sex were used. They were housed in clean polypropylene cages under standard conditions of humidity $(50 \pm 5 \%)$, temperature $\left(25 \pm 2{ }^{\circ} \mathrm{C}\right)$ and light $(12 \mathrm{~h} \mathrm{light} / 12 \mathrm{~h}$ dark cycle) and fed a standard diet (Amrut laboratory animal feed, Pune, India) and water ad libitum. All animals were handled with humane care. Experimental protocols were reviewed and approved by the Institutional Animal Ethics Committee (Animal House Registration No.25/1999/CPCSEA) and conform to the Indian National Science Academy Guidelines for the Use and Care of Experimental Animals in Research.

\section{Preparation of test and reference drug solutions}

Garcinia indica extract (GIE) was dissolved in distilled water and the aqueous solution was used. Silymarin was suspended in an aqueous solution of $1 \%$ carboxymethyl cellulose and administered.

\section{Experimental procedure}

(Faremi et al., 2008; Pramyothin et al., 2007; Naik \& Panda, 2007)

Animals, after acclimatization (6-7 days) in the animal quarters, were randomly divided into five groups of six animals each and treated in the following manner:

Group I served as normal control and received distilled water orally once daily for 28 days.

Group II served as toxicant control and received ethanol (5 g/kg, 20\% w/v p.o.) once daily for 21 days from day 8 to day 28 .

Group III, termed GIE400, received GIE $(400 \mathrm{mg} / \mathrm{kg}$, p.o.) daily for 28 days and ethanol ( $5 \mathrm{~g} / \mathrm{kg}, 20 \% \mathrm{w} / \mathrm{v}$ p.o.) daily for 21 days from day 8 to day 28 .

Group IV, termed GIE800, received GIE $(800 \mathrm{mg} / \mathrm{kg}$, p.o.) daily for 28 days and ethanol ( $5 \mathrm{~g} / \mathrm{kg}, 20 \% \mathrm{w} / \mathrm{v}$ p.o.) daily for 21 days from day 8 to day 28 .

Group V received silymarin $(200 \mathrm{mg} / \mathrm{kg}$, p.o.) for 28 days and ethanol (5 g/kg, $20 \%$ w/v p.o.) daily for 21 days from day 8 to day 28 .

All the animals were humanely sacrificed using ether, $24 \mathrm{~h}$ after the last dose administration. Blood (3-4 mL) was collected by cardiac puncture under light ether anesthesia and allowed to clot for $30 \mathrm{~min}$ at room temperature. The serum was separated by centrifugation in an pathological centrifuge at $1,200 \times \mathrm{g}$ at $30{ }^{\circ} \mathrm{C}$ for $15 \mathrm{~min}$, and used for the determination of marker enzymes (aspartate aminotransferase (AST), alanine aminotransferase (ALT) and alkaline phosphatase (ALP)), serum triglyceride (sTG), albumin (Alb) and total protein (TP). The livers were dissected immediately, washed with ice-cold saline and divided into two equal parts. One part was used to prepare a $10 \%(\mathrm{w} / \mathrm{v})$ homogenate in $1.15 \% \mathrm{KCl}$. An aliquot was used for the determination of lipid peroxidation (LPO). The homogenates were centrifuged in refrigerated tabletop centrifuge at $7,000 \times \mathrm{g}$ for $10 \mathrm{~min}$ at $4{ }^{\circ} \mathrm{C}$ and the supernatants were used for the assays of triglyceride 
(hTG), GSH, SOD, CAT, GPx and GR. The remaining part of the liver was fixed in $10 \%(\mathrm{w} / \mathrm{v})$ buffered formalin and used for histological studies.

\section{Marker enzyme assays}

The liver marker enzymes AST, ALT and ALP were assayed in serum using standard kits supplied from Span Diagnostics (Surat, India). The results were expressed as IU/L.

\section{Protein determination}

The levels of TP and Alb were determined in the serum of experimental animals by using the Lowry method and the bromocresol green method, respectively (Lowry et al., 1951; Webster et al., 1974). Kits purchased from Span Diagnostics (Surat, India) were used for Alb assay.

\section{Triglyceride determination}

Triglyceride levels were determined in the serum and tissue homogenate of experimental animals by using kits purchased from Biolab Diagnostics Ltd. (Mumbai, India)

\section{Lipid peroxidation}

The quantitative determination of LPO was performed by measuring the concentration of thiobarbituric acid reactive substances (TBARS) in the liver using the method of Ohkawa (Ohkawa et al., 1979). The amount of malondialdehyde (MDA) formed was quantified by the reaction with TBA and used as an index of lipid peroxidation. The results were expressed as nanomole of MDA per gram of wet tissue using molar extinction coefficient of the chromophore $\left(1.56 \times 10^{-5} / \mathrm{M} / \mathrm{cm}\right)$ and 1,1,3,3-tetraethoxypropane as standard.

\section{Glutathione determination}

GSH was assessed in the liver homogenate using DTNB by the method of Ellman (Ellman, 1959). The absorbance was read at $412 \mathrm{~nm}$ and the results were expressed as micromole per gram of wet tissue.

\section{Antioxidant enzyme assays in liver homogenate}

SOD was assayed by the method of Sun and Zigman in which the activity of SOD was inversely proportional to the concentration of its oxidation product adrenochrome, which was measured spectrophotometrically at $320 \mathrm{~nm}$ (Sun \& Zigman, 1978). One unit of SOD activity is defined as enzyme concentration required to inhibit the rate of auto-oxidation of epinephrine by $50 \%$ in $1 \mathrm{~min}$ at $\mathrm{pH} 10$.

CAT was determined by the method of Clairborne, which is a quantitative spectroscopic method developed for following the breakdown of $\mathrm{H}_{2} \mathrm{O}_{2}$ at $240 \mathrm{~nm}$ in unit time for routine studies of CAT kinetics (Clairborne, 1985).

GPx determination was carried out using the method of Rotruck et al. (1973) which makes use of the following reaction:

$\mathrm{H}_{2} \mathrm{O}_{2}+2 \mathrm{GSH} \rightarrow 2 \mathrm{H}_{2} \mathrm{O}+\mathrm{GSSG}$ (oxidized glutathione)

GPx in the tissue homogenate oxidizes glutathione and simultaneously $\mathrm{H}_{2} \mathrm{O}_{2}$ is reduced to water. This reaction is arrested at $10 \mathrm{~min}$ using trichloroacetic acid and the remaining glutathione is reacted with DTNB solution to result in a colored compound, which is measured spectrophotometrically at $420 \mathrm{~nm}$ (Rotruck et al., 1973).

GR activity was determined by using the method of Mohandas et al., in which the following reaction is implicated:

$\mathrm{NADPH}+\mathrm{H}^{+}+\mathrm{GSSG} \rightarrow \mathrm{NADP}^{+}+2 \mathrm{GSH}$

In the presence of GR, oxidized glutathione undergoes reduction and simultaneously NADPH is oxidized to $\mathrm{NADP}^{+}$. Enzyme activity is quantified at room temperture by measuring the disappearance of NADPH/min at $340 \mathrm{~nm}$ spectrophotometrically (Mohandas et al., 1984).

\section{Histopathological studies}

The parts of the livers which were stored in $10 \%(\mathrm{w} / \mathrm{v})$ buffered formalin were embedded in paraffin, sections cut at $5 \mu \mathrm{m}$ and stained with hematoxylin and eosin $(\mathrm{H} / \mathrm{E})$. These sections were then examined under a light microscope for histo-architectural changes.

\section{Statistical analysis}

The results of hepatoprotective and antioxidant activities are expressed as mean \pm SEM. Results were statistically analyzed using one-way ANOVA, followed by the TukeyKramer post test for individual comparisons. The $p<0.05$ was considered to be significant.

\section{Results}

\section{Biochemical parameters}

The effects of GIE on serum marker enzymes AST, ALT and ALP and serum Alb, TP and serum triglycerides are summarized in Figures 1-3. Significant elevation in the marker enzyme activities and triglyceride levels, and depletion in Alb and TP content was observed in the ETOH-treated group of animals when compared with normal animals. Treatment of GIE400, GIE800 and silymarin to rats intoxicated with ETOH decreased significantly $(p<0.001)$ the elevated activity of AST. However, ALT and AST activities were significantly decreased only by GIE800 and silymarin administration ( $p<0.05$ and $p<0.01$ respectively). ETOH treatment significantly $(p<0.001)$ decreased serum TP levels which were restored by GIE 800 and silymarin significantly $(p<0.05$ and $p<0.01$ respectively) and the Alb levels were restored by treatment with GIE800, GIE400 and silymarin insignificantly. The serum triglyceride levels elevated by ETOH treatment were significantly restored $(p<0.05)$ by GIE 800 treatment, which was comparable to the effect of silymarin.

The effects of GIE on antioxidant enzymes, GSH, LPO and hTG are summarized in Table 1. MDA, the lipid peroxidation marker was significantly elevated $(p<0.01)$ in the ETOH control group of rats when compared with the normal group. Treatment with GIE800 and silymarin to ETOH-intoxicated rats increased significantly $(p<0.05$ and $p<0.01$ respectively) the decreased levels of GSH, while GIE400 restored the GSH levels insignificantly. 


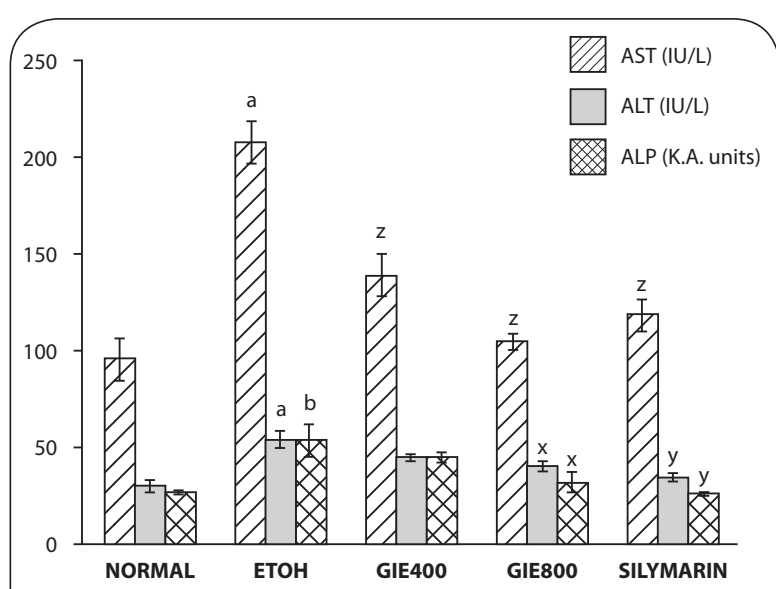

Figure 1. Effect of Garcinia indica extract on serum marker enzymes in ethanol intoxicated rats. $p$-values: $a<0.001, b<0.01$ when ETOH Control compared with Normal Control; $x<0.05$, $y<0.01, z<0.001$ when Experimental groups compared with ETOH Control.

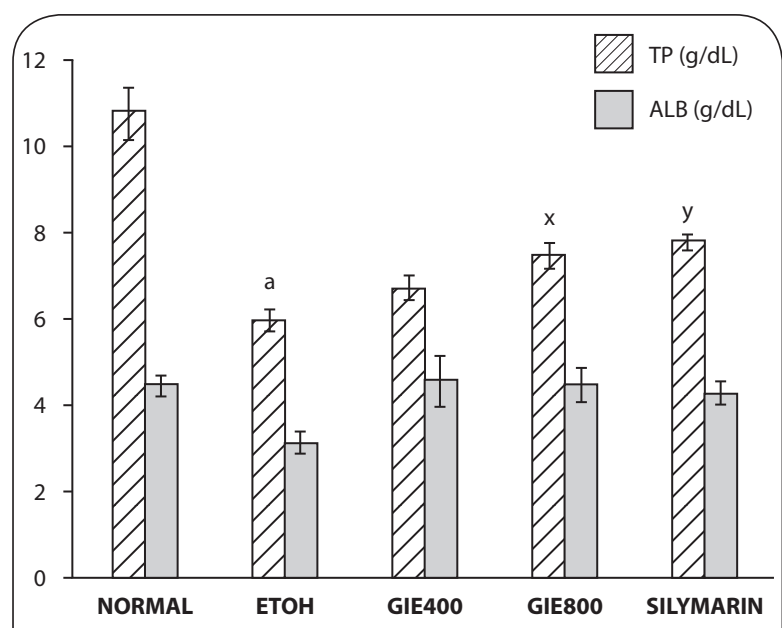

Figure 2. Effect of Garcinia indica extract on serum albumin and total proteins in ethanol intoxicated rats. $p$-values: ${ }^{a}<0.001$ when ETOH Control compared with Normal Control; $x<0.05, y<0.01$ when Experimental groups compared with ETOH Control.

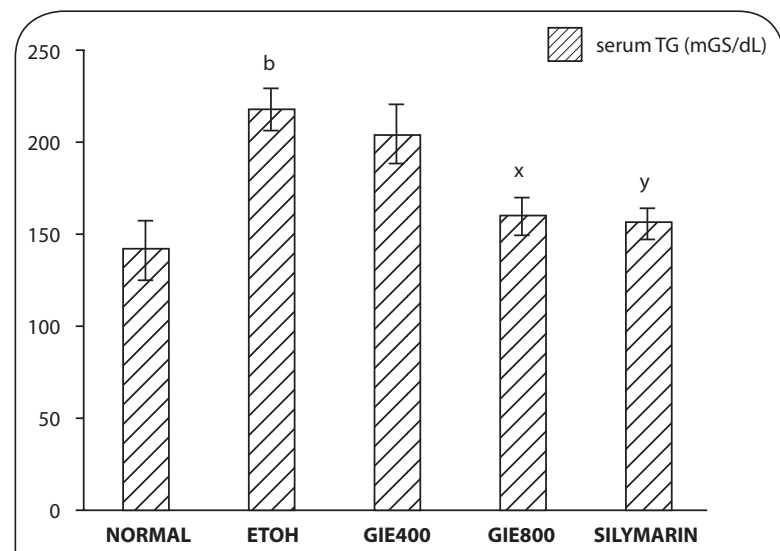

Figure 3. Effect of Garcinia indica extract on serum triglycerides in ethanol intoxicated rats. $p$-values: ${ }^{b}<0.01$ when ETOH Control compared with Normal Control; $x<0.05, y<0.01$ when Experimental groups compared with ETOH Control.
A significant decline in GSH levels $(p<0.001)$ was observed in the ETOH treated group when compared with the normal control group of rats. Treatment with GIE800 and silymarin to ETOH-intoxicated rats increased significantly ( $p<0.05$ and $p<0.01$ respectively) the decreased levels of GSH, while GIE400 restored the ETOH elevated levels insignificantly.

Liver SOD activity was found to be strikingly lower $(p<0.001)$ in ETOH treated rats when compared with normal rats. Treatment with GIE800 and silymarin significantly ( $p<0.01$ and $p<0.001$ respectively) restored SOD activity to normal, while GIE400 restored SOD activity insignificantly.

The CAT activity in livers of the ETOH treated group was found to be significantly $(p<0.01)$ lower than in the normal group. GIE800 and silymarin treatments increased the ETOH-depleted CAT activity significantly $(p<0.01)$.

GPx activity was depleted significantly $(p<0.001)$ by ETOH treatment. Treatment with GIE400, GIE 800 and silymarin restored significantly $(p<0.05, p<0.01$ and $p<0.01$ respectively) the ETOH-depleted GPx activity.

GR activity was depleted significantly $(p<0.001)$ by ETOH treatment. Treatment with GIE800 and silymarin restored significantly ( $p<0.05$ and $p<0.01$ respectively) the ETOH-depleted GR activity.

Hepatic triglyceride levels were significantly elevated $(p<0.001)$ in the ETOH control group of rats when compared with the normal group. Treatment of GIE400, GIE800 and silymarin to ETOH-intoxicated rats depleted hepatic triglyceride levels significantly $(p<0.001)$.

\section{Histopathological studies}

The livers of animals of the normal group showed normal histology (Figure 4). The liver sections of animals treated with ETOH (Figure 5) showed a moderate to marked degree of fatty changes. There were moderate to severe abscesses and hemorrhage. The central veins showed congestion with congestion of sinusoids. Many hepatocytes showed degenerative changes. Moderate degree of mononuclear inflammatory infiltration was seen within all zones. Compared with the lesions observed in the ETOH group, the lesions noted in livers of silymarin treated animals were of a much milder degree (Figure 6). Few of the central veins and sinusoids showed dilatation with focal congestion and minimal fatty changes. Mild stromal inflammatory infiltration comprising lymphocytes and macrophages were seen also within the periportal and focal midzonal areas. Regenerative foci of mild to moderate degree were noted in these areas. The livers in the GIE400 group (Figure 7) showed mild to moderate degree of mononuclear inflammatory infiltration within all zones. Moderate fatty changes and few regenerative cells were noted. The GIE800 group (Figure 8) showed mild to moderate degree of mononuclear inflammatory infiltrations within all zones. Mild to minimal fatty changes around the dilated central vein were seen and many regenerative cells were noted. Histo-architecture of GIE800 treated rats tended to be more normal compared to GIE400, while silymarin treated rats showed almost normal histology. 
Table 1. Effect of GIE on liver TBARS, GSH, SOD, CAT, GPX, GR and hTG in ETOH- intoxicated rats.

\begin{tabular}{|c|c|c|c|c|c|}
\hline $\begin{array}{l}\text { Biochemical } \\
\text { parameters }\end{array}$ & $\begin{array}{l}\text { Group I } \\
\text { Normal } \\
\text { Control } \\
\text { distilled } \\
\text { water }\end{array}$ & $\begin{array}{c}\text { Group II } \\
\text { Toxicant } \\
\text { Control } \\
\text { ETOH } \\
(5 \mathrm{~g} / \mathrm{kg}, 20 \% \mathrm{w} / \mathrm{v})\end{array}$ & $\begin{array}{l}\text { Group III } \\
\text { GIE } \\
\text { (400 mg/kg) }\end{array}$ & $\begin{array}{l}\text { Group IV } \\
\text { GIE } \\
(800 \mathrm{mg} / \mathrm{kg})\end{array}$ & $\begin{array}{l}\text { Group V } \\
\text { Silymarin } \\
(200 \mathrm{mg} / \mathrm{kg})\end{array}$ \\
\hline $\begin{array}{l}\text { TBARS } \\
\text { (nmol MDA/g wet tissue) }\end{array}$ & $34.72 \pm 4.07$ & $59.31 \pm 7.32^{b}$ & $50.69 \pm 1.01$ & $39.86 \pm 1.62^{x}$ & $34.89 \pm 1.77 y$ \\
\hline $\begin{array}{l}\text { GSH } \\
\text { ( } \mu \mathrm{mol} / \mathrm{g} \text { wet tissue) }\end{array}$ & $1.33 \pm 0.03$ & $1.04 \pm 0.02^{\mathrm{a}}$ & $1.08 \pm 0.01$ & $1.15 \pm 0.02^{x}$ & $1.19 \pm 0.02^{y}$ \\
\hline $\begin{array}{l}\text { SOD } \\
\text { (U/mg protein) }\end{array}$ & $43.57 \pm 0.86$ & $32.60 \pm 1.55^{\mathrm{a}}$ & $36.61 \pm 2.35$ & $42.23 \pm 1.81 y$ & $43.55 \pm 0.84^{z}$ \\
\hline $\begin{array}{l}\text { CAT } \\
\text { (U/mg protein) }\end{array}$ & $5.13 \pm 1.05$ & $1.50 \pm 0.28^{b}$ & $3.11 \pm 0.11$ & $4.69 \pm 0.37 y$ & $5.02 \pm 0.71 y$ \\
\hline $\begin{array}{l}\text { GPx } \\
\text { (U/mg protein) }\end{array}$ & $2.5 \pm 0.32$ & $1.00 \pm 0.27 \mathrm{a}$ & $1.96 \pm 0.06^{x}$ & $2.28 \pm 0.13 y$ & $2.4 \pm 0.19 y$ \\
\hline $\begin{array}{l}\text { GR } \\
\text { (U/mg protein) }\end{array}$ & $798.32 \pm 35.44$ & $256.15 \pm 61.89^{a}$ & $437.38 \pm 28.30$ & $467.03 \pm 75.98^{x}$ & $576.25 \pm 31.58^{y}$ \\
\hline $\begin{array}{l}\mathrm{hTG} \\
(\mathrm{mg} / \mathrm{dL})\end{array}$ & $2.37 \pm 0.30$ & $13.21 \pm 1.01^{a}$ & $6.07 \pm 0.57 z$ & $4.40 \pm 0.24 z$ & $2.85 \pm 0.33^{z}$ \\
\hline
\end{tabular}

Values are mean \pm SEM for 6 animals in each group

$p$-values: $\mathrm{a}<0.001, \mathrm{~b}<0.01, c<0.05$ when Toxicant Control compared with Normal Control; $\mathrm{x}<0.05, \mathrm{y}<0.01, \mathrm{z}<0.001$ when Experimental groups compared with Toxicant Control

1 unit of $\mathrm{CAT}=\mu \mathrm{mol} \mathrm{H}_{2} \mathrm{O}_{2}$ consumed $/ \mathrm{min} / \mathrm{mg}$ protein

1 unit of GPx $=\mu \mathrm{g}$ GSH utilized $/ \mathrm{min} / \mathrm{mg}$ protein

1 unit of GR $=$ nmol NADPH oxidized $/ \mathrm{min} / \mathrm{mg}$ protein

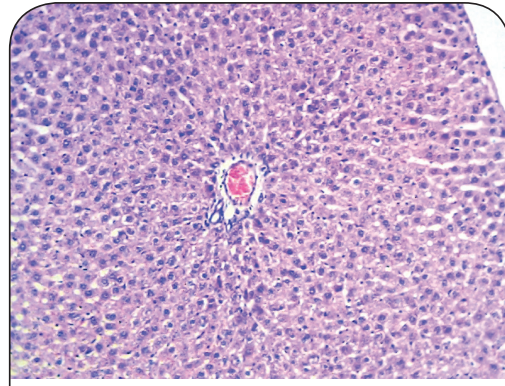

Figure 4. H/E staining of liver tissue of normal rats $(100 x)$

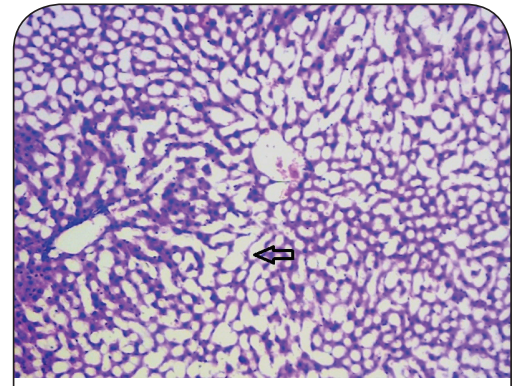

Figure 5. H/E staining of liver tissue of ethanol treated rats $(100 \times)$.

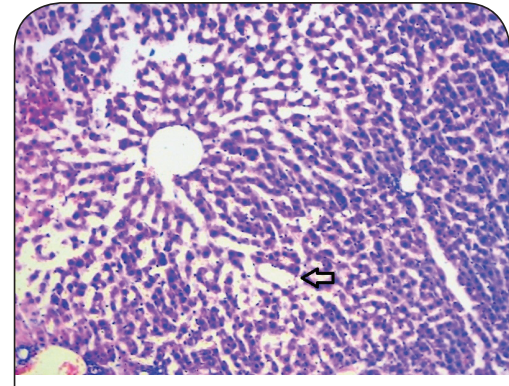

Figure 6. H/E staining of liver tissue of rats treated with ethanol and silymarin $(200 \mathrm{mg} / \mathrm{kg})(100 \times)$.
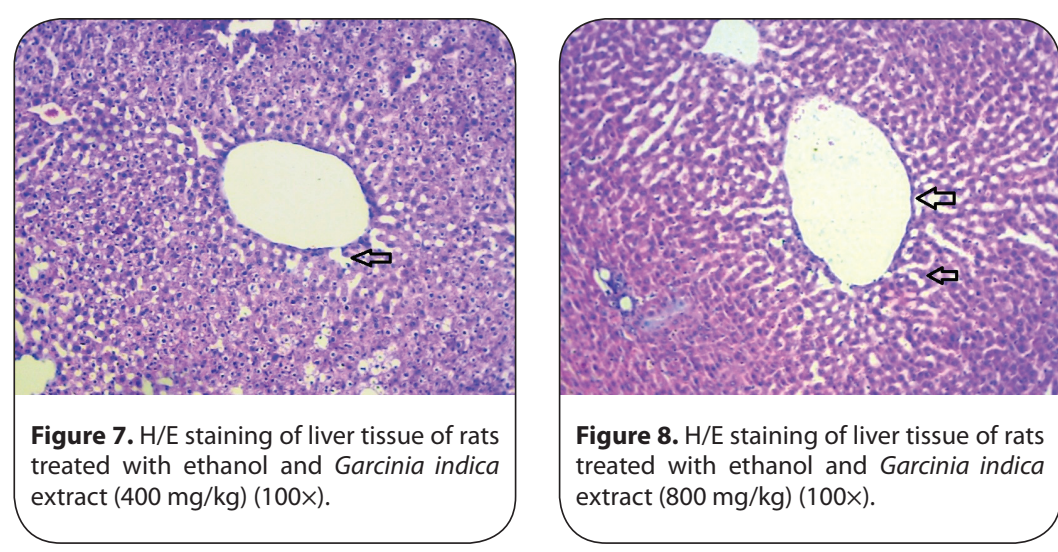

Figure 8. $\mathrm{H} / \mathrm{E}$ staining of liver tissue of rats treated with ethanol and Garcinia indica extract $(800 \mathrm{mg} / \mathrm{kg})(100 \times)$.

\section{Discussion}

The close relation between ethanol and liver damage is mainly due to the fact that about $80 \%$ of ingested alcohol is metabolized in the liver. Ethanol is metabolized into cytotoxic acetaldehyde by the enzyme alcohol dehydrogenase in the liver. Acetaldehyde is oxidized to acetate by aldehyde oxidase or xanthine oxidase, giving rise to various ROS via cytochrome P450 2E1 (Tuma \& Casey, 2003). Alcohol damages also the mitochondria, 
resulting in decreased ATP production (Thurman et al., 1984a). In addition, alcohol depletes the endogenous antioxidants and thereby, induces oxygen deficiency (hypoxia) creating a state of oxidative stress (Thurman et al., 1984a; b).

Assessment of liver function can be performed by determining the activity of serum enzymes AST, ALT and ALP, originally present in high concentrations in the cytoplasm. When there is hepatic injury, these enzymes leak into the blood stream in conformity with the extent of liver damage. The elevated activities of these marker enzymes in sera of the ETOH-treated rats in the present study were due to the extensive liver damage caused by the toxin. Treatment with the test drug GIE (in both doses) as well as the reference drug silymarin significantly reduced the ETOH induced elevation in the activities of these enzymes.

Triglycerides are an important part of the cholesterol profile that is often measured quantitatively for diagnosis of primary and secondary hyperlipoproteinemia, dyslipidemia, triglyceridemia and liver obstruction. Results of the present study revealed increased serum triglyceride levels in ethanol fed rats, suggestive of decreased lipoprotein lipase enzyme activity, which is responsible for uptake of lipoprotein by extra-hepatic tissues. Decreased hepatic triglyceride level in GIE treated rats reflects the protective hepatocellular effect. According to the findings of Walker and Gordan, fatty infiltration of the liver occurs in rats after prolonged ingestion of ethanol (Walker \& Gordon, 1970). Alterations in lipid metabolism brought about by ethanol can produce decreased oxidation, increased hepatic fatty acid synthesis, decreased triglyceride conversion and marked hepatic triglyceride accumulation (Walker \& Gordon, 1970; Johnson, 1995).

Ethanol aggravates lipid peroxidation, as evident from the present study. Oral administration of GIE decreased the lipid peroxidation of cellular memberane, suggesting a protective effect. The increase in MDA levels in the livers of ETOH treated rats suggests enhanced peroxidation leading to tissue damage and failure of the antioxidant defense mechanisms to prevent the formation of excessive free radicals (Naik, 2003). Treatment with GIE significantly reversed these changes. It is thus likely that the mechanism of hepatoprotection of GIE lies in its antioxidant activity.

Reduced glutathione is one of the most abundant non-enzymatic antioxidant bio-molecules present in tissues (Meister, 1984). Its functions are removal of free oxygen species, such as $\mathrm{H}_{2} \mathrm{O}_{2}$, superoxide anions \& alkoxy radicals, maintenance of membrane protein thiols, and it acts as a substrate for GPx and glutathione $S$-transferase (GST) (Townsend et al., 2003). In the present study, decreased GSH levels in ETOH intoxicated rats may have been caused by its increased utilization for augmenting the activities of GPx \& GST and for detoxification of acetaldehyde during chronic ethanol exposure. GSH levels depleted by ETOH were significantly restored by GIE, either due to increased synthesis of GSH or due to stimulation of GR activity.
Free radical scavenging enzymes, such as SOD, CAT \& GPx, are known to be the first line cellular defense enzymes against oxidative damage, disposing $\mathrm{O}_{2}$ \& $\mathrm{H}_{2} \mathrm{O}_{2}$ before their interaction to form the more harmful hydroxyl $\left(\mathrm{OH}^{*}\right)$ radical (Ji et al., 1988). In the present study, SOD activity decreased significantly in the ETOH treated group of animals, which might be due to an excessive formation of superoxide anions. These excessive superoxide anions might inactivate SOD and decrease its activity. In the absence of adequate SOD activity, superoxide anions are not dismuted into $\mathrm{H}_{2} \mathrm{O}_{2}$, which is the substrate for the $\mathrm{H}_{2} \mathrm{O}_{2}$ scavenging enzymes CAT \& GPx. This results in inactivation of the $\mathrm{H}_{2} \mathrm{O}_{2}$ scavenging enzymes CAT and GPx, leading to a decrease in their activities. Administration of GIE to ETOH intoxicated rats effectively prevented the depletion of SOD, CAT \& GPx activities, which can be correlated to the scavenging of free radicals by GIE, resulting in protection of these enzymes.

GR is an antioxidant enzyme involved in the reduction of GSSG (an endproduct of GPx reaction) to GSH. In ETOH treated rats, there was a marked depletion of GPx activity, leading to reduced availability of the substrate for GR, thereby decreasing the activity of GR. Oral treatment of GIE to ETOH intoxicated rats restored the activity of GR, thus accelerating the conversion of GSSG to GSH and enhancing the detoxification of reactive metabolites by conjugation with GSH.

The hepatoprotective effect of GIE may thus be attributed to an underlying antioxidant activity, which prevents the process of initiation and progress of hepatocellular injury. As confirmed by histopathological studies, the effects of GIE were comparable with those of silymarin, a proven hepatoprotective.

In conclusion, the hepatoprotective effect of GIE against ETOH-induced hepatotoxicity in rats appears to be related to the inhibition of lipid peroxidative processes and to the prevention of GSH depletion. The present study highlighted the health benefits of kokum, establishing it as a potent "functional food" and promoting its use as a culinary spice to enrich people's diets. Moreover, it is cheap, readily available to all strata of society, with medicinal properties attributed to it.

\section{Acknowledgement}

We thank Ranbaxy Laboratories, New Delhi, India for providing a gift sample of silymarin. We are grateful to Glenmark Research Centre, Mumbai, India for providing animals for this study.

\section{REFERENCES}

Albano E, French SW, Ingelman-Sundberg M. (1999). Hydroxyethyl radicals in ethanol hepatotoxicity. Front Biosci 4: D533-D540.

Balasubramanyam K, Altaf M, Varier RA, Swaminathan V, Ravindran A, Sadhale PP, Kundu TK. (2004). Polyisoprenylated benzophenone, garcinol, a natural histone acetyltransferase inhibitor, represses chromatin transcription and alters global gene expression. J Biol Chem 279(32): 33716-33726. 
Clairborne A. (1985). Catalase activity, in CRS Handbook of Methods in Oxygen Radical Research (Greenwald RA ed) pp. 283-284, CRS Press, Boca Raton.

Devasagayam TPA, Tilak JC, Bapat MM, Mishra A. (2006). Antioxidant activity of Garcinia indica (kokam) and its syrup. Curr Sci 91: 90-93.

Ellman GL. (1959). Tissue sulphydryl groups. Arch Biochem Biophys 82(1): 70-77.

Faremi TY, Suru SM, Fafunso MA, Obioha UE. (2008). Hepatoprotective potentials of Phyllanthus amarus against ethanol-induced oxidative stress in rats. Food Chem Toxicol 46(8): 2658-2664.

linuma M, Tosa H, Tanaka T, Kanamaru S, Asai F, Kobayashi Y, Miyauchi K, Shimano R. (1996). Antibacterial activity of some Garcinia benzophenone derivatives against methicillin-resistant Staphylococcus aureus. Biol Pharm Bull 19(2): 311-314.

Jena BS, Jayaprakasha GK, Singh RP, Sakariah KK. (2002). Chemistry and biochemistry of (-)-hydroxycitric acid from Garcinia. J Agric Food Chem 50(1): $10-22$.

Ji LL, Stantman FW, Lardy HA. (1988). Antioxidant enzyme systems in rat liver and skeletal muscle. Arch Biochem Biophys 263(1): 150-160.

Johnson PT. (1995). The Assessment of Hepatic Function and Investigation of Jaundice, in Clinical Biochemistry-Metabolic and Clinical Aspects (Marshall WJ, Bangert SK eds) 1st ed. pp. 220, Churchill Livingstone, New York.

Khare CP. (2007). Indian Medicinal Plants: An Illustrated Dictionary. $2^{\text {nd }}$ ed. pp. 278-279, Springer, New York.

Krishnamurthy N, Sampathu SR. (1988). Antioxidant principles of Kokum rind J Food Sci Technol 25: 44-45.

Lowry OH, Rosebrough NJ, Farr AL, Randall RJ. (1951). Protein measurement with the Folin phenol reagent. J Biol Chem 193(1): 265-275.

Mantelingu K, Reddy BA, Swaminathan V, Kishore AH, Siddappa NB, Kumar GV, Nagashankar G, Natesh N, Roy S, Sadhale PP, Ranga U, Narayana C, Kundu TK. (2007). Specific inhibition of p300-HAT alters global gene expression and represses HIV replication. Chem Biol 14(6): 645-657.

Meister A. (1984). New aspects of glutathione biochemistry and transport selective alterations of glutathione metabolism. Nutr Rev 42(12): 397-410.

Mohandas J, Marshal JJ, Duggin GG, Horvath JS, Tiller DG. (1984). Low activities of glutathione-related enzymes as factors in the genesis of urinary bladder cancer. Cancer Res 44(11): 5086-5091.

Naik SR. (2003). Antioxidants and their role in biological functions: an overview. Indian Drugs 40: 501-516.

Naik SR, Panda VS. (2007). Antioxidant and hepatoprotective effects of Ginkgo biloba phytosomes in carbon tetrachloride-induced liver injury in rodents. Liver Int 27(3): 393-399.

Ohkawa H, Ohishi N, Yagi K. (1979). Assay of lipid peroxidation in animal tissues by thiobarbituric acid reaction. Anal Biochem 95(2): 351-358.

Padhye S, Ahmad A, Oswal N, Sarkar FH. (2009). Emerging role of Garcinol, the antioxidant chalcone from Garcinia indica Choisy and its synthetic analogs. J Hematol Oncol 2: 38-51.
Pan MH, Chang WL, Lin-Shiau SY, Ho CT, Lin JK. (2001). Induction of apoptosis by garcinol and curcumin through cytochrome $\mathrm{c}$ release and activation of caspases in human leukemia HL-60 cells. J Agric Food Chem 49(3): 1464-1474

Panda VS, Ashar HD. (2012). Antioxidant and hepatoprotective activity of Garcinia indica extract Choisy fruits in carbon tetrachloride-induced liver injury in rats. J Food Biochem 36(2): 240-247.

Pramyothin P, Ngamtin C, Poungshompoo S, Chaichantipyuth C. (2007). Hepatoprotective activity of Phyllanthus amarus Schum. et. Thonn. extract in ethanol treated rats: in vitro and in vivo studies. J Ethnopharmacol 114(2): 169-173.

Rotruck JT, Pope AL, Ganther HE, Hofeman DG, Hoekstra WG. (1973). Selenium: Biochemical role as a component of glutathione peroxidase. Science 1979(4073): 588-590.

Rukachaisirikul V, Naklue W, Sukpondma Y, Phongpaichit S. (2005). An antibacterial biphenyl derivative from Garcinia bancana MIQ. Chem Pharm Bull 53(3): 342-343.

Shastri BN. (1956). The Wealth of India - A Dictionary of Indian Raw Materials and Industrial Products. Pp. 101-103, CSIR, New Delhi, India.

Sun M, Zigman S. (1978). An improved spectrophotometric assay for superoxide dismutase based on epinephrine auto-oxidation. Anal Biochem 90(1): 81-89.

Thurman RG, Ji S, Matsumura T, Lemasters JJ. (1984a). Is hypoxia involved in the mechanism of alcohol-induced liver injury? Fundam Appl Toxicol 4: 125133.

Thurman RG, Ji S, Lemasters JJ. (1984b). Alcohol-induced liver injury. The role of oxygen. Recent Dev Alcohol 2: 103-117.

Tuma DJ, Casey CA. (2003). Dangerous byproducts of alcohol breakdown-Focus on adducts. Alcohol Res Health 27(4): 285-290.

Townsend DM, Tew KD, Tapiero H. (2003). The importance of glutathione in human disease. Biomed Pharmacother 57(3-4): 144-155.

Walker JEC, Gordon ER. (1970). Biochemical aspects associated with an ethanol-induced fatty liver. Biochem J 119(3): 511-516.

Webster D, Bignell AH, Attwood EC. (1974). An assessment of the suitability of bromocresol green for the determination of serum albumin. Clin Chim Acta 53(1): 101-108.

Wu D, Cederbaum Al. (2003). Alcohol, oxidative stress and free radical damage. Alcohol Res Health 27(4): 277-284.

Yamaguchi F, Ariga T, Yoshimura Y, Nakazawa H. (2000a). Antioxidative and anti-glycation activity of garcinol from Garcinia indica fruit rind. J Agric Food Chem 48(2): 180-185.

Yamaguchi F, Saito M, Ariga T, Yoshimura Y, Nakazawa H. (2000b). Free radical scavenging activity and antiulcer activity of garcinol from Garcinia indica fruit rind. JAgric Food Chem 48(6): 2320-2325. 